\title{
E-Atmosferin Plansız Satın Alma Davranışı Üzerindeki Etkisinde Alışveriş Keyfinin Aracılık Rolü: Tüketicilerin Atmosfer Duyarlılıklarına Göre Bir Karşılaştıma
}

\section{The Mediating Role of Shopping Enjoyment on the Effect of e-Atmospherics on Impulse Buying Behavior: A Comparison on the Atmospheric Responsiveness of Consumers}

\section{Ece Bayramoğlư - Kübra Tuğçe Özata ${ }^{2}$ - Doç. Dr. Oylum Korkut Altuna Prof. Dr. F. Müge Arslan 4}

Başvuru Tarihi: 13.06 .2018

Kabul Tarihi: 18.02.2019

\section{Öz}

Günümüzde e-ticaretin gelişmesi ve tüketiciler için e-ticaret sitelerinin oldukça yoğun olarak tercih edilen bir kanal haline dönüşmesi ile birlikte, bu alana olan akademik ilgi de artmıştır. Literatür incelendiğinde, e-alışveriş davranışları ve e-tüketiciler üzerine yürütülen çalışmalar arasında e-ticaret sitesine ilişkin çeşitli unsurların e-alışveriş davranışı üzerindeki etkilerinin farklı perspektiflerden ele alındiğı görülmektedir. Bu çalışmanın amacı, e-atmosferin plansız satın alma davranışı ve alışveriş keyfi üzerindeki etkilerinin incelenmesi ve bu ilişkide alışveriş keyfinin aracılık etkisinin e-tüketicilerin atmosfer duyarlılı düzeylerine göre test edilmesidir.

Araştırma kapsamında kolayda örnekleme yöntemi kullanılarak 234 cevaplayıcı üzerinde çevrimiçi anket yapılmıştır. Araştırma sonucunda alışveriş keyfi değişkeninin e-atmosferin plansız satın alma davranışı üzerindeki etkisinde tüm örneklem için ve farklı atmosfer duyarlılı̆̆ seviyelerine (düşük/yüksek) sahip gruplar için tam aracılık rolü üstlendiği tespit edilmiştir.

Anahtar Kelimeler: E-Atmosfer, E-Atmosferik Unsurlar, Alışveriş Keyfi, Plansız Satın Alma, Atmosfer Duyarlılı̆g

\footnotetext{
Abstract

${ }^{1}$ İstanbul Üniversitesi Sosyal Bilimler Enstitüsü, ece.bayramoglu@hotmail.com, ORCID: 0000-0003-1665-348X

${ }^{2}$ İstanbul Üniversitesi Sosyal Bilimler Enstitüsü, k.t.ozata@gmail.com, ORCID: 0000-0003-1665-348X

${ }^{3}$ İstanbul Üniversitesi Siyasal Bilgiler Fakültesi, oaltuna@istanbul.edu.tr, ORCID: 0000-0003-1665-348X

${ }^{4}$ Marmara Üniversitesi İșletme Fakültesi, mugearslan@marmara.edu.tr, ORCID: 0000-0003-1665-348X
}

Nowadays academic interest in e-consumer behavior has increased as a result of the substantial development of e-commerce and the significant growth in the usage of e-commerce sites as a marketing channel by consumers. Review of previous literature reveals a number of studies dealing with the relationship between various characteristics of web sites and their effects on e-consumers and their 
behavior from different perspectives. The aim of this study is to investigate the effects of e-atmospherics on impulse buying behavior and shopping enjoyment and to test the mediating role of shopping enjoyment on this relationship according to the atmospheric responsiveness levels of e-consumers.

In the study, convenience sampling was used where 234 surveys were collected using online survey method. The results of the study show that shopping enjoyment has a statistically significant mediating role on the relationship between atmospherics and impulse buying behavior for the total sample and for the two different levels (low/high) of atmospheric responsiveness groups.

Keywords: E-Atmospherics, E-Atmospheric Cues, Shopping Enjoyment, Impulse Buying, Atmospheric Responsiveness

\section{Giriş}

Tüketici davranışları, her geçen gün önemi daha da artan bir konu haline gelmektedir. Tüketici davranışlarına konu olan "birey", küresel ve makro çevresel koşullar gereği kendini yenileyen, her an istekleri farklılaşabilen karmaşık bir varlıktır ve bu nedenle tüketici davranışları da sürekli değişim gösteren, dinamik bir alandır. Son yıllarda işletme alanında görülen değişimler sonucunda istek ve ihtiyaçların karşılanması açısından tüketicileri memnun etmek daha da güç hale gelmiştir. Tüketiciler mal veya hizmeti daha hızlı elde etmeye, tek seferde ihtiyaçlarını tek merkezden karşılamaya ihtiyaç duymaktadırlar (Özmen, 2009). Özellikle teknolojinin gelişimi ve internetten pazarlamanın oldukça yaygınlaşması, pazarlama profesyonelleri ve akademisyenlerini de bu ortamdaki tüketici davranışlarını anlama çabası içine yöneltmiştir. İnternetten alışverişin yaygınlaşmasında, tüketicilerin bilgiye ulaşma maliyetini azaltması ve perakendecilerin iş yapma maliyetlerini düşürmesinin etkili olduğu bilinen bir gerçektir. Internet kullanım oranı Türkiye'de 2017 yılında 16-74 yaş grubundaki bireylerde \%66,8 oranına ulaşmıştır (http://www.tuik.gov.tr, 24.04.2018). Bu artış, internet üzerinden alışveriş oranının da yükselmesine ve bunun sonucu olarak e-ticaret sistemine ilişkin dinamiklerin anlaşılması yönünde gerekliliğin artmasına neden olmuştur. Bu bağlamda e-ticaret, e-perakendecilik, e-tüketici davranışları, e-mağazacılık gibi alanlarda profesyonel araştırmaların yanı sıra akademik çalışmaların sayısının da büyük artış gösterdiği görülmektedir.

Perakendecilikte, mağaza çekiciliğini artırmak ve tüketiciler açısından mağazayı çekici kılacak mağaza atmosferi oluşturmaya yönelik çok sayıda araştırma ile karşılaşmak mümkündür (ör. Kotler, 1973-1974; Bitner, 1992; Turley ve Milliman, 2000; Mattila ve Wirtz, 2001; Baker vd, 2002). Geleneksel mağazacılıkta olduğu gibi, e-mağazacılıkta da mağaza atmosferi unsurlarının önemi vurgulanmaktadır. Bilindiği gibi, mağaza atmosferinde beş duyu organına hitap edilebilirken, emağazacılıkta sadece görsel ve işitsel unsurlar kullanılarak e-atmosfer yaratılabilmektedir (Arslan, 2011), ancak atmosfer yaratmadaki mantık her iki mağaza ortamında da aynıdır. E-perakendecilikte mağaza atmosferi üzerine belirli çalışmalar bulunmaktadır (örneğin, Chang ve Chen, 2008; Davis vd.. 2008; Manganari vd. 2009; Mazaheri vd., 2013; Koo ve Park 2017). E-atmosfer konusuna odaklanan söz konusu çalışmalarda da, geleneksel perakendecilik çalışmalarında olduğu gibi Uyarıcı- 
Organizma-Tepki (U-O-T) (Stimulus-Organism-Response, S-O-R) modelinin temel alındığ görülmektedir (Eroğlu vd., 2003; Wu vd., 2008; Kim ve Lennon, 2009; Manganari vd., 2009; Koo ve $\mathrm{Ju}, 2010$ ). Mağaza atmosferi, U-O-T modeli çerçevesinde uyarıcı olarak yer almakta ve tüketici davranışları üzerinde büyük bir etkiye sahip olduğu bilinmektedir (Eroğlu vd.. 2003; Kim ve Lennon, 2009).

Mağaza atmosferi konusunda ilgili literatür incelendiğinde çok sayıda çalışmanın yer aldığı görülmekle beraber, tüketicilerin mağaza atmosfer duyarlılıklarını ele alan ve mağaza atmosferinin tüketici davranışları üzerindeki etkilerini mağaza atmosfer duyarlılığı perspektifi ile değerlendiren çalışmaların sayısının oldukça kısıtlı olduğu görülmektedir (Eroğlu vd., 2001; Fiore ve Kim, 2007). Bu araştırmanın bu açıdan literatürde önemli bir boşluğu doldurması beklenmektedir.

Son yıllarda, tüketicilerin ihtiyaç oluştuğunda satın alma gerçekleştiren bireylerden çok, ihtiyaç oluşmadan anlık karar verip satın alma gerçekleştiren bireylere dönüştükleri gözlemlenmektedir (Özgüven, 2015). Tüketicilerin sıklıkla, anlık oluşan, önceden planlanmamış, ürünü gördükleri anda satın almaya yönelik davranışlar sergiledikleri görülmektedir. Bunun farkında olan işletmeler de tüketicileri plansız satın almaya yönelten uygulamalar başlatmış ve plansız satın almayı tetikleyen unsurları mercek altına almaya başlamışlardır. Bu unsurlardan biri olan mağaza atmosferi unsurları da tüketicileri plansız satın almaya yönlendirmede büyük bir etkiye sahiptir. Literatürde U-O-T modeli temel alınarak geliştirilen mağaza atmosferi çalışmalarında plansız satın alma davranışının bağımlı değişken olarak ele alındığı çalışmaların sayısı oldukça fazladır (Parboteeah vd., 2009; Spies vd., 1997). Bahsi geçen çalışmalar incelendiğinde mağaza atmosferi unsurları ile plansız satın alma davranışı ilişkisinde alışveriş keyfinin aracılık etkisinin de test edildiği çalışmalara rastlanmıştır (Koufaris 2002; Adelaar, 2003; Verhagen ve Dolen, 2011). Bu araştırmada da benzer şekilde, alışveriş keyfinin aracılık etkisi test edilecektir. Yapılan literatür taraması sonucunda sözkonusu etkilerin Türkiye'de e-perakende ortamında test edilmediği anlaşıldığından çalışmanın bir boşluğu dolduracağı düşünülmekte, konu ile ilgilenen akademisyen ve pratisyenlere 1 şı tutması beklenmektedir.

Tüm bu unsurlar göz önünde bulundurularak, eldeki çalışmada e-atmosferin plansız satın alma davranışı ve alışveriş keyfi üzerindeki etkilerinin ve e-atmosfer ile plansız satın alma davranışı ilişkisinde alışveriş keyfinin aracılık etkisinin cevaplayıcıların atmosfer duyarlılık seviyelerine göre test edilmesi amaçlanmaktadır.

\section{Teorik Çerçeve ve Hipotez Geliştirme}

Çevresel psikoloji kapsamında; mağaza atmosferi uyarıcı; tüketici tutumları duygu ve bu tutumlar sonucunda tüketicilerin geliştirdiği tepki ise davranış olarak tanımlanmaktadır (Mehrabian ve Russell, 1974; Donovan ve Rossiter, 1982). Mehrabian ve Russell'ın 1974'te oluşturduğu Uyarıcı (Stimulus)-Organizma (Organism)-Tepki/davranış (Response) (U-O-T:S-O-R) modeli birçok çalışmaya temel teşkil etmektedir. U-O-T modeli, bireylerin çevrelerine nasıl tepki verdikleriyle ilgili temel bir modeldir. Bu modelin önemli önermelerinden birisi, duyguların müşterilerin hizmet ortamlarına tepkilerinin temel tetikleyicisi olmasıdır (Mehrabian ve Russell, 1974). Mehrabian ve Russell (1974) bireyleri çevreleyen birçok uyarıcının (çevresel uyaran) olduğunu ve bu uyarıcıların 
bireyler üzerinde etki yaratarak, onları çeşitli davranışlara yönlendirdiğini vurgulamaktadırlar. $\mathrm{Bu}$ yaklaşıma göre, çevresel uyaranlar bireylerde memnuniyet, uyarılma ve baskınlık boyutlarında duygulara sebep olmaktadır (Mehrabian ve Russell, 1974). Bireyin bu uyaranlara nihai tepkisi ise yaklaşma veya kaçınma olarak iki temel davranışla sonuçlanmaktadır (Donovan ve Rossiter, 1982; Russell ve Snodgrass, 1987). U-O-T modelini temel alan çalışmalarda duyguların tüketicilerin satın alma davranışları üzerinde etkisi olduğu bulgularına ulaşılmıştır (Donovan ve Rossiter, 1982; Sherman vd., 1997). Tüketici davranışı, bu model içerisinde değerlendirildiğinde Uyarıcı, birey için dışsal bir faktördür ve bu faktör hem pazarlama karması unsurlarından hem de diğer çevresel unsurlardan oluşur. Organizma, uyarıcı ve bireyin tepkileri arasındaki ilişkiye aracılık eden bilişsel ve duygusal aracı durumları ve süreçleri ifade eder (Mehrabian ve Russell, 1974). Tepki ise, tutum ve/veya davranış gibi belirli davranış ve psikolojik tepkileri içeren son faaliyet ya da tüketici reaksiyonudur (Bagozzi, 1986). Mağaza unsurlarının tüketici davranışları üzerindeki etkilerinin literatürde genellikle U-O-T modeli kapsamında ele alındığı görülmektedir (Spies vd., 1997; Eroğlu, 2003). E-perakendecilik üzerine yapılan çalışmalar incelendiğinde U-O-T modelinin geleneksel mağazacılıkta olduğu kadar, e-mağaza alışverişlerindeki tüketici davranışlarını inceleyen çalı̧malara da temel teşkil ettiği görülmektedir (Eroğlu, 2003; Wu vd., 2008; Kim ve Lennon, 2009; Manganari vd., 2009; Koo ve Ju, 2010). Bir başka deyişle, sanal satın alma sürecinde de, U-O-T modelinin, web temelli uyarıcıların sanal tüketici davranışları üzerindeki etkilerinin incelenmesinde temel alındığı söylenebilir (Dahlén ve Lange 2002; Deng ve Poole 2012; Li, 2011).

Atmosfer, alıcılar üzerinde belirli duyusal etkiler yaratmak ve satın alma olasılıklarını artırmak için bilinçli olarak satın alma ortamının tasarlanmasıdır (Kotler, 1973-1974). Kotler’a (1973-1974) göre, bir ürünün en önemli özelliklerinden biri satın alındığı veya tüketildiği yer olmakta olup, bazı durumlarda satın alma kararı üzerinde üründen daha da fazla etkiye sahip olabilmektedir. Diğer bir deyişle bazı durumlarda, atmosfer birincil ürün konumuna gelmektedir. Kotler (1973-1974), atmosfer unsurlarını, görsel (renk, boyut, şekil), işitsel, dokunsal ve koku gibi ana duyusal bileşenler olarak sinıflandırmaktadır.

Baker vd., (2002) atmosferi, ortam unsurları (örneğin, aydınlatma ve müzik) ve sosyal unsurlar (örneğin, çalışanların sayısı/güler yüzlülüğü) olarak sınıflandırmış ve bu unsurların memnuniyet, uyarılma ve satın alma isteği üzerindeki etkilerini incelemiş̧ir. Atmosfer ve atmosfer unsurlarının tüketiciler üzerinde yarattığı etkiyi ölçen birçok çalışma yapılmıştır (ör. Donovan ve Rossiter 1982; Turley ve Milliman, 2000; Baker, 2002; Eroğlu vd., 2003; Manganari vd., 2009; Kim vd., 2009; Floh ve Madlberger 2013, Mazaheri vd., 2013). Atmosfer ile ilgili yapılan birçok çalışma Donovan ve Rossister’n uyguladığı gibi U-O-T modeline dayanmaktadır (Bitner, 1992; Eroğlu, Machleit ve Davis,1999; Eroğlu, Machleit ve Davis, 2003; Floh ve Madlberger, 2003; Xu,2007; Koo ve Park, 2017). Bitner (1992) ise, fiziksel çevrenin sosyal unsur üzerindeki etkisini (çalışanlar ve müşteriler), hizmet kuruluşlarının atmosfer özelliklerine odaklanan kavramsal bir modelle sunmuştur. Atmosfer unsurlarının (sosyal, tasarım ve ortam) mağaza seçim kriterlerini değerlendirmede etkili olduğu bilinmektedir (Baker vd., 2002). Y kuşağı üzerine yapılan bir araştırmada, mağaza atmosferi unsurlarının tüketicilerin duygu durumları (memnuniyet ve uyarılma) üzerinde etkili olduğu ve 
bunun sonucunda anlık satın alma davranışını olumlu yönde etkilediği bulgusuna ulaşılmıştır (Xu, 2007).

Sanal alışverişin ortaya çıkışından ve hızla gelişmeye başlamasından itibaren bu alanda yapılan diğer araştırmalar kadar e-atmosfer unsurları ve bu unsurların tüketici davranışı üzerindeki etkilerini inceleyen çalışmalar da artış göstermiştir. E-perakendecilikte çevresel unsurlar görev ilişkili olma düzeylerine göre (yüksek/düşük) ikiye ayrılmaktadır (Eroğlu vd., 2001). Yüksek görev ilişkili unsurlar, ekranda görünen ve tüketicinin alışveriş hedefine ulaşmasını kolaylaştıran ve etkinleştiren tüm site tanımlayıcıları (sözel/görsel) olarak tanımlanmaktadır. Yüksek görev ilişkili unsurlar tüketicinin fonksiyonel beklentilerine cevap verir. Düşük görev ilişkili unsurlar ise, tüketicinin fonksiyonel beklentileri olmadığı durumlarda etkili olur ve alışveriş görevinin tamamlanması için nispeten önemsiz olan site bilgilerini temsil eder, örneğin sitedeki renkler, ürün dışındaki diğer resimler, müzikler, vs. Bu unsurların yaklaşma (veya kaçınma) tepkilerine müdahale eden içsel durumları (duygusal ve bilişsel) etkilediği ortaya koyulmaktadır. Eroğlu vd., (2003) tarafından yürütülen deneysel çalışma sonuçlarına göre, müşterinin tutumu, tatmin düzeyi ve yaklaşma/kaçınma davranışı üzerinde e-mağaza atmosferinin belirgin bir etkisi bulunmaktadır. Sözkonusu çalışmada, U-O-T modeline göre U (Uyarıcı) atmosfer unsurlarını, O (Organisma) müşterilerin duygusal tepkilerini, T (Tepki) ise yaklaşma/kaçınma davranışını temsil etmektedir.

U-O-T modeli temelli çalışmalarda Uyarıcı (U) olarak mağaza atmosferinin kullanıldığı durumlarda, Tepki (T) olarak Plansız Satın Alma değişkeninin test edildiği çalışmalar olduğu görülmektedir (Spies vd., 1997; Morrin ve Chebat, 2005). Plansız satın alma davranışına yönelik pek çok araştırmacı çeşitli kavramsal tanımlamalarda bulunmuştur. Stern (1962) plansız satın alma davranışını "alışverişçinin daha önceden planlamadan yaptığı herhangi bir satın alma eylemi” olarak tanımlamıştır. Beatty ve Ferrell (1998)'e göre ise plansız satın alma, "tüketicinin belli bir ürün kategorisinden önceden satın alma niyeti olmadan veya belirli bir satın alma görevini yerine getirme niyeti olmadan, ani ve çabuk bir davranıştır”. Rook (1987) ise plansız satın alma davranışını, bir tüketicinin herhangi bir uyarana maruz kaldığında ortaya çıkan pozitif etkilenme neticesinde gerçekleşen plansız alışveriş olarak tanımlamıştır. Plansız satın alma davranışı, ürünün tüketiciler tarafından görülmesi veya ürünü temsil eden uyarıcının fark edilmesiyle başlamaktadır. Plansız satın almada tüketici, çevresel unsurlardan etkilenerek anlık olarak çok yoğun bir duygu seline kapılır ve kendisinde mutlaka satın alma gerektiği hissi oluşur. Dolayısıyla, müşterilerin plansız satın alma kararında o anda var olan dişsal etkiler söz konusudur. Bu dişsal etkilerin başında mağaza atmosferi unsurları gelmektedir. Ancak söz konusu dişsal etkiden etkilenme düzeyi atmosfer duyarlılığı derecesine göre fark gösterebilmektedir.

\section{E-Atmosferik Unsurlar}

Geleneksel mağazalarda olduğu gibi e-mağazacılıkta da atmosfer unsurları müşterilerin e-mağaza imajı algısı ve e-mağaza deneyimi üzerinde etkilidir (Eroğlu vd., 2001). Web sitesi atmosferi (eatmosfer), "olumlu tüketici tepkilerini (sitenin yeniden ziyareti gibi) arttırmak amacıyla kullanıcılar üzerinde olumlu etkiler oluşturmak için web sitesi ortamının bilinçli bir şekilde tasarlanması” şeklinde tanımlanmaktadır (Dailey, 2004, s.796). Sanal alışverişte, web sitesi atmosferi ve atmosfer unsurları tüketicilerin içsel durumlarını ve alışveriş tutumlarını etkilemektedir. Sözkonusu atmosfer unsurlarının neler olduğu ve tüketicileri nasıl etkilediği yönünde pek çok çalışma yapılmıştır. Daha 
önce de değinildiği gibi, Eroğlu vd., (2001) atmosfer unsurlarını yüksek ve düşük görev ilişkili olarak incelemişler ve yüksek görev ilişkili unsurların, alışverişin asıl amacına uygun olan, malın tanımı, fiyatı, teslimi, iadesi ile ilgili sözel içerikler, ürün resimleri veya gezinme unsurlarını içerdiğinden; düşük görev ilişkili unsurların ise alışverişin asıl hedefi dışında kalan, sözel içerikler, renkler, animasyonlar, yazı tipleri, müzikler, ürün dışı görseller, bağlantıları vb. kapsadığından bahsetmişlerdir. McKinney (2004) tüketicilerin internet alışverişine yönelik yönelimlerini belirleme amacıyla yola çıktığı çalışmasında sanal atmosferi, dış değişkenler, iç değişkenler, düzen, satın alma noktaları ve müşteri hizmetleri şeklinde beş sınıfta ele almaktadır. Hausman ve Siekpe (2009) ise, web arayüz özelliklerinin tüketici satın alma niyeti üzerindeki etkisini ele aldığı çalışmasında web atmosferini insan ve bilgisayar faktörleri olarak ikiye ayırmıştır. Bilgisayar faktöründe (onay kutuları, menüler, butonlar vb.) gibi işlevsellik özellikleri baskındır. İnsan faktörü ise, keyif, bilişsel sonuçlar, kullanıcı yetkilendirmesi, güvenilirlik, görsel görünüm ve bilgi içeriği özelliklerini kapsamaktadır. Yapılan araştırmalarda, sanal atmosfer unsurlarının (müzik ve renk), tüketicilerin duygusal tepkileri üzerinde önemli bir etkisi olduğu sonucuna ulaşılırken (Wu vd., 2008); tasarım, atmosfer, sosyal yapı gibi e-mağaza atmosfer unsurlarının tüketici davranışlarını çeşitli yönlerden etkilediği saptanmıştır (Manganari vd., 2009). Koo ve Ju'nun 2010'da Güney Kore’de yaptıkları araştırmada, sanal mağaza atmosferi unsurlarının (grafik, renk, bağlantı ve menü) müşteri duygulanımları (memnuniyet ve uyarılma) üzerinde ve bu duygu durumlarının da müşterilerin satın alma niyetleri üzerinde etkili olup olmadığı test edilmiştir. Elde edilen bulgulara göre, menü hariç diğer atmosfer unsurlarının memnuniyet ve uyarılma üzerinde olumlu etkileri olduğu görülmüştür. Bir başka araştırmada, Kuzey Amerika, Çin ve Orta Doğu'da, duyguların ve e-atmosfer unsurlarının (bilişim, etkinlik ve eğlence) tüketici tutumlarına etkisini ortaya konulmuştur (Mazaheri vd., 2013). Davis vd. İse, 2008 yılında yaptıkları çalışmada, Çinli ve Amerikalı sanal müşteriler için, kültürün atmosfer unsurları üzerindeki etkilerini incelemiş ve anlamlı sonuçlara ulaşmışlardır. Parboteeah vd. (2009), web sitesi özelliklerinin plansız satın alma davranışı üzerindeki etkisini inceledikleri çalışmada, bu özellikleri ikiye ayırmışlardır: görevle ilgili unsurlar ve ruh haliyle ilgili unsurlar. Görevle ilgili unsurlar (güvenlik, gezinme, bilgi, indirme), faydacı olup doğrudan müşterinin işini görmesini sağlayan web sitesi özellikleri iken; ruh haliyle ilgili unsurlar (memnuniyet, görsellik) ise müşteriler üzerinde duygu durumu yaratan özelliklerdir. İlgili çalışmada, web sitesinin hem yüksek kalitede görevle ilgili unsurları hem de ruh haliyle ilgili unsurları sağladığında, sanal plansız satın alma davranışı ihtimalini ve alışveriş miktarının büyüklüğünü maksimize edeceği sonucuna ulaşmışlardır. Koo ve Park'ın (2017) çalışmasında, atmosfer unsurlarının memnuniyet üzerinde etkisi olup olmadığı ve bu tepkinin tüketicilerin yaklaşım davranışına yol açıp açmadığı araştırılmıştır. Sözkonusu çalışmada atmosfer unsurları görsel, bilgi, gezinme ve sosyal olmak üzere dört grupta incelenmiştir. Görsel unsur dışındaki diğer atmosfer unsurlarının memnuniyet üzerinde etkisi olduğu sonucuna ulaşılmıştır. Floh ve Madlberger (2013) ise atmosfer unsurlarını, tasarım, içerik, gezinme olarak üç boyutta ele almış ve bu unsurların plansız satın alma üzerindeki etkilerini incelemiştir. Çalışma sonucunda atmosfer unsurlarının plansız satın almada önemli bir rolü olduğunu saptamışlardır.

\section{Plansız Satın Alma}

Literatürde yer alan araştırmalar, sanal mağaza atmosferi unsurlarının plansız satın alma üzerindeki etkilerini ortaya koymaktadır. Adelaar (2003) çalışmasında harekete geçirme etkisi olarak duyguların plansız satın alma üzerinde etkin olduğunu ortaya koymuştur. Bununla birlikte medya formatlarının 
ne duygular ne de plansız satın alma üzerinde herhangi bir etkisi bulunduğunu göstermiştir. Parboteeah ve Wells (2009), web sitesi unsurlarının (iş ile ilgili göstergeler ve ruh hali ile ilgili göstergeler) plansız satın alma üzerindeki etkisini, algılanan fayda ve algılanan haz durumlarının aracılık etkisiyle test etmiştir. Çalışmanın sonunda, plansız satın alma eğiliminin ruh hali ile ilgili göstergelere karşı hassas olduğu ve bu göstergelerden etkilendiği sonucuna varılmıştır. Verhagen ve Dolen (2011) ise, sanal mağaza ile ilgili değişkenlerin (mağaza çekiciliği, sitenin kullanım kolaylığı, keyif ve web sitesi iletişim tarzı), tüketici sanal plansız satın alma davranışı ile ilişkisini incelenmişlerdir. Plansız satın alma davranışının \%40'nın sanal harcamalar olarak gerçekleşmesi bulgusundan yola çıkarak tasarlanan çalı̧mada, pozitif ve negatif duyguların aracılık etkisi test edilmiştir. Araştırma bulgularına göre, olumlu etkilenme duygusunun sanal plansız satın almanın temel öncüllerinden biri olduğunu ortaya koymuştur. Bressolles, 2007'de yaptığı çalışmada sanal hizmet kalitesi bileşenlerinin müşteri tatmini ve plansız satın alma üzerindeki etkilerini incelemiştir. Elde edilen sonuçlara göre, müşteri tatmininin plansız satın alma üzerinde anlamlı bir etkisi olduğu görülmüştür. Böylece aşağıdaki hipotez geliştirilmiştir:

H1: E-Atmosferin plansız satın alma üzerinde istatistiksel olarak anlamlı bir etkisi vardır.

\section{Alışveriş Keyfi}

Alı̧veriş keyfi, alışveriş sürecinde elde edilen memnuniyet olarak tanımlanmaktadır (Beatty ve Ferrell 1998). Shun ve Yunjie (2006) alışveriş keyfini, bir e-mağazadaki alışveriş deneyiminin, beklenen herhangi bir performans sonucundan bağımsız olarak, kendi başına eğlenceli olarak algılanma derecesi olarak ifade etmektedir. Bellenger ve Korgaonkar (1980), alı̧veriş yapmaktan hoşlanan müşterilerin daha fazla plansız satın alma gerçekleştirdiklerini vurgulamaktadır. Beatty ve Ferrell (1998) alısveriş keyfinin, doğrudan tüketicilerin ruh halleriyle ilişkili olduğunu ortaya koymuştur. Etüketiciler, olumlu his yaratan alışverişten keyif almakta ve bunun sonucu plansız alışveriş gerçekleştirmektedirler. Koufaris (2002), önceki çalışmaları temel alarak, alışveriş keyfinin plansız satın alma üzerinde olumlu bir etkiye sahip olup olmadığını test etmiş ancak beklenmedik bir sonuç olarak, alışveriş keyfinin plansız satın alma üzerinde bir etkisi olmadığı sonucuna ulaşmış̧ır. $\mathrm{Bu}$ çalışmanın aksine, Adelaar (2003), uyaranlara karşı olumlu duygusal tepkilerin plansız satın alma niyetini arttırdığını göstermiştir. Verhagen ve Dolen (2011) tarafından yapılan çalı̧ma, alışveriş keyfi ve plansız satın alma arasında anlamlı bir ilişki olduğunu ortaya koymuştur. Aynı şekilde, Mohan vd. (2013) de, alı̧veriş keyfinin plansız satın alma üzerinde olumlu bir etkisi olduğu bulgusuna ulaşmışlardır. Ayrıca, yapılan araştırmalara göre, tüketicilerin sanal mağaza ortamına ilişkin algılarının alışveriş keyfi ve alışveriş katılımı üzerinde olumlu etkileri vardır (Kim vd., 2007). Bu bilgiler eşiğinde aşağıdaki hipotezler geliştirilmiştir:

H2: E-Atmosferin alı̧veriş keyfi üzerinde istatistiksel olarak anlamlı bir etkisi vardır.

H3: Alışveriş keyfinin plansız satın alma üzerinde istatistiksel olarak anlamlı bir etkisi vardır.

H4: Alı̧veriş keyfinin, e-atmosferin plansız satın alma üzerindeki etkisinde aracılık etkisi bulunmaktadır. 


\section{Atmosfer Duyarlılığı}

Atmosfer duyarlılığı, müşterinin nerede ve nasıl alışveriş yapacağını ve alışverişe ne kadar zaman harcayacağını belirleyen unsurlardan biridir (Eroglu vd., 2001). Atmosfer duyarlılığı McKechnie (1974) tarafından, mağazanın fiziksel özelliklerine bağlı olarak tüketicinin bir mağazadan alışveriş yapma ve oradan satın alma kararı eğilimi olarak tanımlanmıştır. Bunun sonucu olarak sanal alışveriş bağlamında, atmosfer duyarlılığın, sanal alışveriş uyaranı ve müşteri duygusal durumu arasındaki ilişkiyi etkilemesi beklenmektedir.

Sanal alışveriş ortamlarına ilişkin daha önce yürütülen çalışmalarda (Eroglu vd., 2001; Fiore ve Kim, 2007) çeşitli web sitesi uyaranları ile tüketicilerin bilişsel ve duygusal tepkileri arasında atmosfer duyarlılı̆̆ 1 seviyesi ve demografik özelliklerin aracılık etkileri test edilmiştir. Özellikle, tüketici bireysel farklılık özelliklerinden biri olarak kabul edilen atmosfer duyarlılığının, tüketicilerin, mağaza atmosferi kalitesine bağlı olarak satın alma kararını nasıl etkilediği (Grossbart vd., 1990) ve web sitesi uyaranlarından kaynaklı duygusal ve bilişsel tepkiler üzerindeki etkilerinin ne olduğunu inceleyen çalışmalara rastlanmaktadır (Eroglu vd., 2001; Fiore ve Kim, 2007).

Eroğlu 2001'de yaptığı çalışmada, tüketicilerin web sitesi uyaranları kaynaklı duygusal ve bilişsel tepkilerinin atmosfer duyarlılığı seviyelerine göre farklılık gösterebildiğini ve sanal alışverişte yüksek atmosfer duyarlılığına sahip olmanın fark yarattığını belirtmiştir. Eroğlu 2003’te yaptığı çalışmada, web sitesi atmosferi ile duygusal tepki (memnuniyet ve uyarılma) arasındaki ilişkiyi araştırmıştır. Eroğlu'nun yaptığ tüketicilerin memnuniyetini daha fazla etkilediği sonucu elde edilmiştir. Bir başka araştırmada (Lennon, 2011) ise, yüksek atmosfer duyarlılığına sahip tüketicilerin, renkli web sitesi tasarımını daha canlı ve etkili bulduğu sonucuna varılmıştır.

Araştırmada test edilen kavramsal model, tüm etkiler gösterilerek, Şekil 1'de verilmiştir.

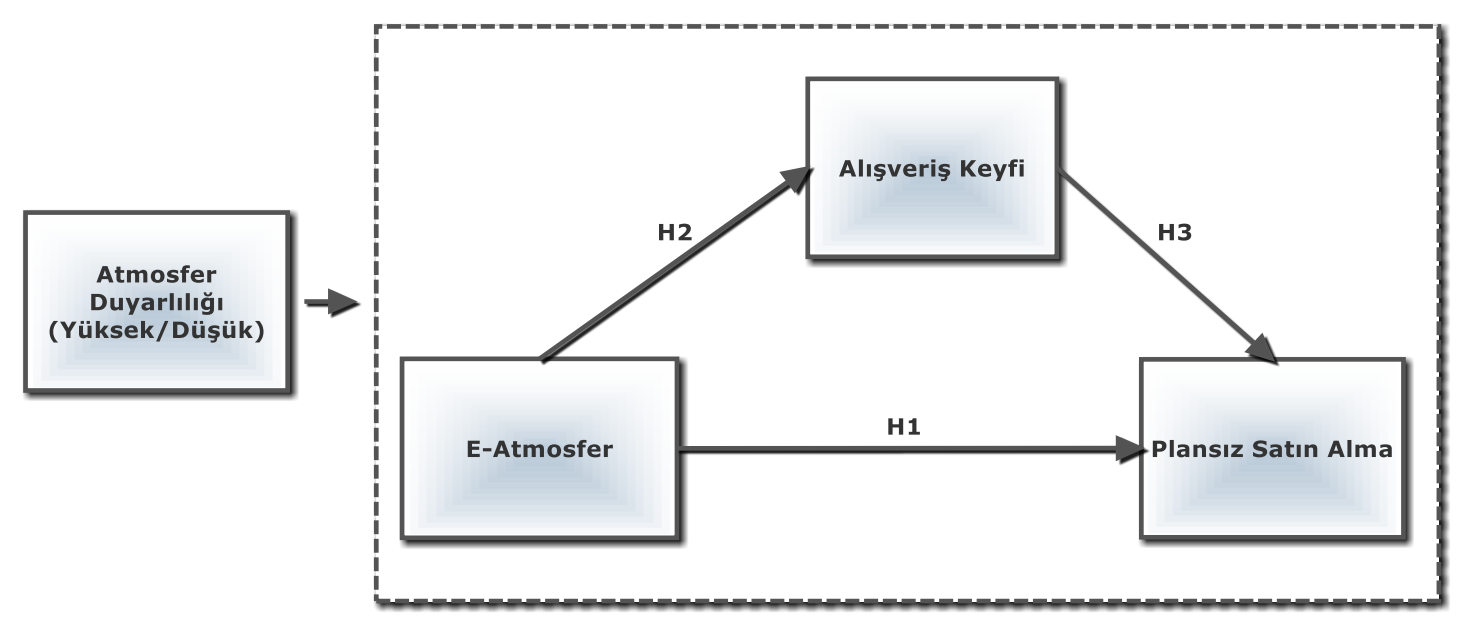

Şekil 1. Tüm Etkilerin Yer Aldığı Kavramsal Model 


\section{Araştırma Metodolojisi}

Çalışmanın amacı e-atmosferin plansız satın alma davranışı ve alışveriş keyfi üzerindeki etkisinin incelenmesi; ayrıca, e-atmosfer ile plansız satın alma davranışı ilişkisinde alışveriş keyfinin aracılık etkisinin test edilmesidir. Çalışmada ilaveten, cevaplayıcıların atmosfer duyarlılığı düzeylerine göre model karşılaştırması yapılarak modeller arasında fark bulunup bulunmadığının tespiti amaçlanmıştır. Araştırma kapsamına dahil edilen e-ticaret sitelerinin belirlenmesi amacı ile Alexa internet sitesi verileri incelenmiş ve bunun sonucunda Türkiye'de en çok kullanılan e-ticaret sitelerinin Trendyol ve Morhipo olduğu görülmüştür (www.alexa.com.24.04.2018). Bu bağlamda, söz konusu araştırma modelinin bu iki alışveriş sitesi dâhilinde test edilmesine karar verilmiştir.

\section{Örneklem, Veri Toplama Yöntemi ve Araştırmada Kullanılan Ölçekler}

Araştırmanın ana kütlesini Morhipo ve Trendyol e-ticaret sitelerinden ürün satın alma deneyimine sahip olan kişiler oluşturmaktadır. Ana kütlenin büyük olması ve ayrıca araştırmadaki zaman ve maliyet kısıtları nedeniyle örneklem alınmasına ve tesadüfi olmayan örnekleme yöntemlerinden kolayda örnekleme yapılmasına karar verilmiştir. Anketler internet yoluyla (çevrimiçi) anket yöntemi ile toplanmıştır. Cevaplayıcıların araştırmaya dâhil edilen e-ticaret sitelerinden alışveriş yapan kişiler arasından seçilmesi amaçlandığından, araştırma anketine "Trendyol/Morhipo e-ticaret sitesinden alışveriş yapıyor musunuz?” filtre sorusu ile başlanmıştır.

Araştırmada kullanılan anket üç bölümden oluşmaktadır. Filtre sorusunun ardından anketin ilk bölümünde e-atmosfer, alışveriş keyfi, plansız satın alma ve alışveriş duyarlılığı değişkenlerine ait ölçek maddelerinden oluşan sorular yer almaktadır. İkinci bölümde cevaplayıcıların demografik bilgilerine ilişkin sorular ve üçüncü bölümde ise e-ticaret sitesindeki alışveriş davranışını belirlemeye yönelik sorular yer almaktadır.

Araştırmada kullanılan e-atmosfer ölçeği, Koo ve Park (2017) çalışmasından alınmış olup, dört boyutta toplanan 18 maddeden oluşmaktadır. Plansız satın alma ölçeği, Yeniçeri vd. (2012)'nin sanal plansız satın alma davranışı üzerine yürüttükleri çalışmadan alınmış olup, beş maddeden ve tek boyuttan oluşmaktadır. Alışveriş keyfi ölçeği, 2013 yılında Beatty ve Ferrell (1998)'in geliştirdiği ölçeği temel alıp çevrimiçi alışveriş ortamına uyarlayan Floh ve Madberger (2013) çalışmasındaki tek boyutlu ve üç maddeden oluşan ölçekten alınmıştır. Atmosfer duyarlılı̆̆ı ölçeği ise, Eroğlu vd. (2003) çalışmasından alınmış olup, dört maddeden oluşan tek boyutlu bir ölçektir. Söz konusu ölçeklerin tümü 5'li Likert tipi ölçeği (1=Kesinlikle Katılmıyorum; 5=Kesinlikle Katılıyorum) kullanılarak ankette yer almıştır.

Araştırma kapsamında toplam 237 anket toplanmış ve uç değer analizi sonucunda 234 kullanılabilir anket araştırmaya dahil edilmiştir.

\section{Verilerin Analizi ve Araştırma Bulguları}

Veri analizi kapsamında araştırmaya katılan cevaplayıcılara ait örneklem profili, ölçek maddelerine ilişkin tanımsal istatistikler, ölçek yapılarına ilişkin güvenilirlik ve geçerlilik testleri ile yapısal eşitlik model testi uygulanmıştır. 


\section{Örneklem Profili}

Araştırmaya katılan cevaplayıcılara ait örneklem profili ve e-site alışveriş alışkanlıkları Tablo 1'de verilmiştir.

Tablo 1. Örneklem Profili ve E-Site Alışveriş Alışkanlıkları

\begin{tabular}{|c|c|c|c|c|c|c|}
\hline & \multicolumn{2}{|c|}{ Toplam Örnek } & \multicolumn{2}{|c|}{ Trendyol } & \multicolumn{2}{|c|}{ Morhipo } \\
\hline & Fre. (N) & Yüz. (\%) & Fre. (N) & Yüz. (\%) & Fre. (N) & Yüz. (\%) \\
\hline \multicolumn{7}{|l|}{ Cinsiyet } \\
\hline Kadın & 186 & 79,8 & 94 & 83,2 & 92 & 76,7 \\
\hline Erkek & 47 & 20,2 & 19 & 16,8 & 28 & 23,3 \\
\hline \multicolumn{7}{|l|}{ Yaş } \\
\hline 18 ve altı & 6 & 2,6 & 4 & 3,5 & 2 & 1,7 \\
\hline $18-20$ & 8 & 3,4 & 6 & 5,3 & 2 & 1,7 \\
\hline $21-25$ & 73 & 31,3 & 49 & 43,4 & 24 & 20,0 \\
\hline $26-30$ & 71 & 30,5 & 21 & 18,6 & 50 & 41,7 \\
\hline $31-40$ & 48 & 20,6 & 21 & 18,6 & 27 & 22,5 \\
\hline $41-50$ & 19 & 8,2 & 9 & 8,0 & 10 & 8,3 \\
\hline $51+$ & 8 & 3,4 & 3 & 2,7 & 5 & 4,2 \\
\hline \multicolumn{7}{|c|}{ İlgili Siteden En Sık Satın Alınan Ürün Grubu } \\
\hline Giyim & 196 & 86,7 & 101 & 91,8 & 95 & 81,9 \\
\hline Aksesuar & 7 & 3,1 & 0 & 0 & 7 & 6,0 \\
\hline Kozmetik & 11 & 4,0 & 5 & 4,5 & 6 & 5,2 \\
\hline Ev eşyası & 2 & 0,9 & 1 & 0,9 & 1 & 9 \\
\hline $\begin{array}{l}\text { Spor } \\
\text { Ekipmanı }\end{array}$ & 3 & 1,3 & 0 & 0 & 3 & 2,6 \\
\hline Diğer & 7 & 3,1 & 3 & 2,7 & 4 & 3,4 \\
\hline \multicolumn{7}{|c|}{ İlgili Sitenin Ayda Ortalama Ziyaret Sıklığı } \\
\hline$<1$ defa & 41 & 17,7 & 13 & 11,5 & 28 & 23,5 \\
\hline 2-5 defa & 100 & 43,1 & 52 & 46,0 & 48 & 40,3 \\
\hline 6-10 defa & 37 & 15,9 & 13 & 11,5 & 24 & 20,2 \\
\hline $11-20$ defa & 28 & 12,1 & 18 & 15,9 & 10 & 8,4 \\
\hline 21-30 defa & 16 & 6,9 & 10 & 8,8 & 6 & 5,0 \\
\hline $31+$ defa & 10 & 4,3 & 7 & 6,2 & 3 & 2,5 \\
\hline \multicolumn{7}{|c|}{ İlgili Site Her Ziyaret Edildiğinde Geçirilen Ortalama Süre } \\
\hline$<1$ saat & 165 & 72,7 & 78 & 71,6 & 87 & 73,7 \\
\hline 1-2 saat & 58 & 25,6 & 29 & 26,6 & 29 & 24,6 \\
\hline 3-4 saat & 3 & 1,3 & 2 & 1,8 & 1 & 0,8 \\
\hline 5-6 saat & 1 & 0,4 & 0 & 0 & 1 & 0,8 \\
\hline \multicolumn{7}{|c|}{ İlgili Site Her Ziyaret Edildiğinde Yapılan Ortalama Harcama } \\
\hline $0-50 \mathrm{TL}$ & 16 & 7,1 & 7 & 6,4 & 9 & 7,8 \\
\hline $51-100 \mathrm{TL}$ & 98 & 43,6 & 52 & 47,7 & 46 & 39,7 \\
\hline $101-250 \mathrm{TL}$ & 87 & 38,7 & 42 & 38,5 & 45 & 38,8 \\
\hline $251-500 \mathrm{TL}$ & 24 & 10,7 & 8 & 7,3 & 16 & 13,8 \\
\hline
\end{tabular}

Tablo 1'de görüldüğü gibi, toplam örneklemin çoğunluğu kadın $(\% 79,8)$ ve 21-25 yaş aralığında $(\% 31,3)$, ilgili siteden ağırlıklı olarak giyim eşyası satın alan $(\% 86,7)$, siteyi ayda ortalama $2-5$ defa ziyaret eden $(\% 43,1)$, her ziyaretinde ortalama bir saatten az süre geçiren $(\% 72,7)$ ve her alışverişinde ortalama 51-100 TL arasında harcama yapan $(\% 43,6)$ kişilerden oluşmaktadır. Alışveriş sitesine göre ayrım yapıldığında ise, örneklem profili toplamla büyük benzerlikler göstermektedir; sadece Morhipo örnekleminde ortalama yaş, toplama ve Trendyol örneklemine göre daha yüksek çıkmıştır (Morhipo: 26-30 yaş aralığı (\%41,7); toplam ve Tredyol: 21-25 yaş aralığı (\%31,3; \%43,4). 


\section{Ölçek Maddelerine ilişkin Ortalama ve Standart Sapma Değerleri}

Araştırmada yer alan ölçek maddelerine ait aritmetik ortalamalar, standart sapmalar Ek 1'de yer almaktadır. Ek 1'e göre, e-atmosfer ölçeğinde yer alan ifadeler içinde en yüksek ortalamayı 3,54 ile "güncel görünüm"; alışveriş keyfi ile ilgili ifadelerde en yüksek ortalamayı 3,73 ile "alışverişin kişiyi mutlu etmesi"; plansız satın alma ile ilgili sorularda en yüksek ortalamayı 3,23 ile "internette gezinirken kişinin düşünmediği şeyleri alması”; ve alışveriş duyarlılığı ile ilgili ifadelerde en yüksek ortalamayı 3,41 ile "internette alışveriş yapılırken sanal mağaza atmosferine dikkat edilmesi" soruları elde etmiştir. E-atmosfer ölçeğinin toplam aritmetik ortalaması 3,29'dur. E-atmosfer ölçeğini oluşturan dört faktör içinde en yüksek ortalama Gezinme Unsurları faktöründen elde edilmiştir olup $(3,52)$, bunu sırasıyla Görsel Unsurlar $(3,43)$, Bilgi Unsurları $(3,40)$ ve Sosyal Unsurlar $(2,77)$ takip etmiştir.

Tablo 2'de ölçeklerin ortalamaları hem tüm örneklem için, hem de iki sanal mağazaya göre (Trendyol ve Morhipo) verilmiştir.

Tablo 2. Ölçeklere Ait Genel Ortalama ve Standart Sapmalar

\begin{tabular}{|c|c|c|c|}
\hline Ölçek & $\begin{array}{c}\text { Toplam Ort. (Std. Sap.) } \\
\mathbf{( N = 2 3 4 )}\end{array}$ & $\begin{array}{c}\text { Trendyol Ort. (Std. Sap.) } \\
\mathbf{( n = 1 1 4 )}\end{array}$ & $\begin{array}{c}\text { Morhipo Ort. (Std. Sap.) } \\
\mathbf{( n = 1 2 0 )}\end{array}$ \\
\hline E-Atmosfer & $3,29(0,97)$ & $\mathbf{3 , 3 7}(\mathbf{0 , 9 2 )}$ & $3,22(1,02)$ \\
\hline Alışver. Keyf. & $\mathbf{3 , 6 5 ( \mathbf { 1 , 2 7 } )}$ & $\mathbf{3 , 7 5}(\mathbf{1 , 2 5})$ & $3,55(1,29)$ \\
\hline Plansız S. A. & $3,07(1,15)$ & $\mathbf{3 , 0 8 ( \mathbf { 1 } , \mathbf { 1 0 } )}$ & $3,07(1,19)$ \\
\hline Atmos. Duy. & $3,22(1,11)$ & $\mathbf{3 , 3 1}(\mathbf{1 , 1 0 )}$ & $3,14(1,11)$ \\
\hline
\end{tabular}

Tablo 2'ye göre, e-atmosfer ölçeğinin toplam aritmetik ortalaması, daha önce belirtildiği gibi, 3,29; alışveriş keyfi 3,65; plansız satınalma 3,07; atmosfer duyarlılığı ise 3,22 olarak elde edilmiştir. En yüksek ortalama alışveriş keyfi için elde edilmiştir. Trendyol ve Morhipo karşılaştırıldığında ise, Trendyol'un tüm değişkenlerde Morhipo'ya nazaran daha yüksek ortalamalar elde ettiği görülmektedir.

\section{Ölçek Yapılarına İlişkin Güvenilirlik ve Geçerlilik Analizleri}

Veri analizine geçilmeden önce araştırmada yer alan tüm ölçeklerin güvenilirlik ve geçerlilik testleri yapılmıştır. Öncelikle araştırmada kullanılan e-atmosferik unsurlar değişkenine ilişkin temel alınan orijinal ölçek dört boyuttan oluştuğu için söz konusu ölçeğin Türkiye'de yapılan araştırma örnekleminde de aynı yapıyı koruyup korumadığının test edilebilmesi için Açıklayıcı Faktör analizi yapılmış ve benzer bir yapının elde edildiği görülmüştür (Ek1). Ancak araştırmanın ana amacı eatmosferik unsurların satın alma niyetine etkisinde alışveriş keyfinin aracılık etkisinin test edilmesi olduğundan, boyutsal yapısı doğrulanan ölçek araştırmanın ilerleyen aşamalarında bütünsel olarak analizlere dahil edilmiştir. 
Ölçeklerin güvenilirliğinin tespiti için, Cronbach's Alfa testinden yararlanılmıştır (Tablo 3). Tablo 3 incelendiğinde, Cronbach's Alfa değerlerinin 0,926-0,972 arasında yer aldığ görülmektedir. Elde edilen alfa değerleri 0,70'in çok üzerinde olduğundan, ölçeklerin yüksek güvenilirliğe sahip olduğu söylenebilir (Nunnally, 1978).

Tablo 3. Ölçeklere Ait Korelasyon, Güvenilirlik ve Açıklanan Ortalama Varyans Değerleri

\begin{tabular}{|c|c|c|c|c|c|c|c|}
\hline Ölçek & $\mathbf{1}$ & $\mathbf{2}$ & $\mathbf{3}$ & $\mathbf{4}$ & $\boldsymbol{\alpha}$ & $\mathbf{C R}$ & AVE \\
\hline E-Atmosferik Unsurlar (1) & $\mathbf{( 0 . 9 0 7 )}$ & & & & 0,972 & 0.988 & 0.823 \\
\hline Alışveriş Keyfi (2) & $0.742^{* *}$ & $\mathbf{( 0 . 9 5 2 )}$ & & & 0,966 & 0.967 & 0.907 \\
\hline Plansız Satın Alma (3) & $0.602^{* *}$ & $0.719^{* *}$ & $\mathbf{( 0 . 8 4 7 )}$ & & 0,926 & 0.910 & 0.718 \\
\hline Atmosfer Duyarlılı̆ı̆ (4) & $0.666^{* *}$ & $0.708^{* *}$ & $0.758^{* *}$ & $\mathbf{( 0 . 8 6 8 )}$ & 0,930 & 0.923 & 0.754 \\
\hline
\end{tabular}
* Çaprazda, parantez içinde yer alan değerler AVE karekök değerleridir.
$*{ }^{*}<0.01$

Tablo 3'te ayrıca ölçekler arasındaki korelasyon değerleri, çaprazda parantez içinde ortalama açıklanan varyans (AVE) karekök değerleri, birleşik güvenilirlik (CR) katsayıları, ve AVE değerleri verilmiştir. Tablo 3'e göre, tüm ölçekler arasındaki korelasyon katsayılarının oldukça yüksek ve anlamlı olduğu görülebilir ( $r$ katsayıları: 0.602-0.758). En yüksek korelasyon katsayısı, plansız satın alma ile atmosfer duyarlılı̆̆

Araştırmada kullanılan ölçeklerin geçerliliklerinin tespit edilebilmesi için ölçekler yakınsak ve ayrıksak geçerlilik açısından incelenmiştir. Yakınsak geçerliliğin sağlanabilmesi için üç koşul bulunmaktadır: (i) ölçeklerde yer alan her bir maddenin faktör yükünün 0,50'den büyük olması; (ii) ölçeklere ait AVE değerlerinin en az 0,50 olması; ve (iii) ölçeklere ait birleşik güvenilirlik katsayılarının (CR) en az 0,70 olmasıdır (Fornell ve Larcker, 1981). Ek 1'de yer alan tablodaki faktör yükleri (yol katsayıları) incelendiğinde, maddelerin faktör yük değerlerinin 0,722-0,983 arasında, dolayısıyla her bir maddenin yük değerinin 0,50'nin çok üzerinde olduğu görülebilir. Tablo 3'de yer alan AVE değerleri incelendiğinde ise, ölçeklerin AVE değerlerinin 0,718-0,907 arasında, dolayısıyla 0,50'den oldukça yüksek olduğu, ölçeklere ait CR değerlerinin ise 0,910-0,988 arasında, dolayısıyla en alt eşik olan 0,70 değerinin oldukça üzerinde olduğu görülmektedir. Söz konusu bulgular tüm üç koşulun da sağlandığını gösterdiğinden, araştırmada yer alan ölçeklerin yakınsak geçerliliklere sahip olduğu rahatlıkla söylenebilir.

Ölçeklerin ayrıksak geçerliliklerinin tespit edilebilmesi için ölçeklerin AVE karekök değerleri ile ölçekler arasındaki korelasyon katsayıları karşılaştırılmaktadır. AVE karekök değerlerinin kendi satır ve sütunundaki korelasyon değerlerinden yüksek olması durumunda ölçeklerin ayrıksak geçerliliğe sahip olduğu belirtilmektedir (Fornell ve Larcker, 1981). Tablo 3'de yer alan AVE karekök değerleri ile korelasyon katsayı değerleri karşılaştırıldığında bahsedilen şartın sağlandığı, dolayısıyla ölçeklerin ayrıksak geçerliliğe sahip olduğu görülmektedir. 
Araştırmada kullanılan ölçekler, Amos 24 programı kullanılarak yapı geçerliliği açısından test edilmiştir. Bu kapsamda, dört boyuttan oluşan e-atmosfer ölçeği için birinci ve ikinci düzey çok faktörlü doğrulayıcı faktör analizi uygulanırken; plansız satın alma, alışveriş keyfi ve atmosfer duyarlılığı ölçekleri için tek faktörlü birinci düzey doğrulayıcı faktör analizi uygulanmıştır. E-atmosfer ve atmosfer duyarlılık ölçeklerinde ilgili teori ile uyum çerçevesinde önerilen hata terimleri arasındaki modifikasyonlar uygulanmıştır. Analiz sonucunda ölçeklere ilişkin elde edilen uyum değerleri Tablo 4'de sunulmuştur.

\section{Tablo 4. Ölçeklerin Uyum Değerleri (DFA)}

\begin{tabular}{|c|c|c|c|c|c|c|c|}
\hline Ölçek & $\chi^{2}$ & df & $x^{2} / \mathrm{df}$ & GFI & CFI & NFI & RMSEA \\
\hline E-Atmosfer & 292,071 & 129 & 2,264 & 0,874 & 0,971 & 0,950 & 0,074 \\
\hline Plansız S. A. & 4,246 & 2 & 2,123 & 0,991 & 0,996 & 0,993 & 0,069 \\
\hline Alışveriş Keyfi & \multicolumn{7}{|c|}{ Mükemmel Uyum Elde Edilmiştir } \\
\hline Atmos. Duy. & 1,537 & 1 & 1,537 & 0,997 & 0,999 & 0,998 & 0,048 \\
\hline $\begin{array}{l}\text { Kabul Edilebilir } \\
\text { Uyum Değerleri } \\
\text { (Malhotra, 2010:732- } \\
\text { 733) }\end{array}$ & & & $1-5$ & $\geq 0.90$ & $\geq 0.90$ & $\geq 0.90$ & $\leq 0.08$ \\
\hline
\end{tabular}

Tablo 4'de görüldüğü üzere, Doğrulayıcı Faktör Analiz (DFA)'leri sonucunda elde edilen uyum değerleri kabul edilebilir sınırlar dahilinde olduğundan ölçeklerin belirtildiği boyutsal yapıları ile doğrulandığı kabul edilmektedir. Doğrulayıcı Faktör Analizi sonuçları, ortalamalar, standart sapmalar ve Ölçme Modeli'nde elde edilen Standardize $\beta$ değerleri Ek 1'de verilmiştir. Uyum değerleri yeterli olduğu için yapısal model analizi aşaması ile devam edilmiştir.

\section{Yapısal Eşitlik Modeli Testi}

Ölçeklerin güvenilirlik ve geçerlilikleri kanıtlandıktan sonra, e-atmofer değişkeninin bağımsız, alışveriş keyfi ve plansız satınalma değişkenlerinin bağımlı değişken olduğu model testi aşamasına geçilmiştir. Yapısal eşitlik modellemesi analizi sonucunda elde edilen modelin uyum değerleri kabul edilebilir düzeyde çıkmıştır $\left(X^{2}=626,268 ; \mathrm{df}=267 ; X^{2} / \mathrm{df}=2,346 ; \mathrm{GFI}=0,820 ; \mathrm{CFI}=0,953 ; \mathrm{NFI}=0,922\right.$; RMSEA=0,076). Modelin yol (standardize $\beta$ ) analizi sonuçlarına göre e-atmosferin plansız satınalma $\left(\beta=0,640, p<0,01\right.$, Kritik Oran=10,184, Standart hata $\left.=0,077, R^{2}=0,41\right)$ ve alışveriş keyfi $(\beta=0,820$; $\mathrm{p}<0,01$, Kritik Oran=16,071, Standart hata $\left.=0,066, \mathrm{R}^{2}=0,67\right)$ üzerinde istatistiksel olarak anlamlı etkisi bulunmuştur. Dolayısıyla, H1 ve H2 hipotezleri desteklenmiştir (bakınız Şekil 2). 


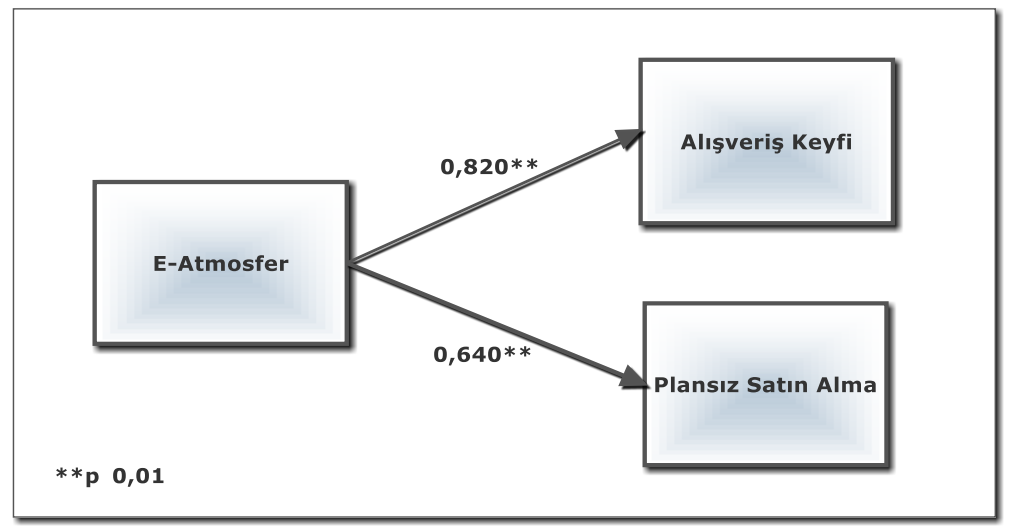

Şekil 2. Yapısal Eşitlik Modeli Test Sonucu

\section{Alışveriş Keyfinin Aracılık Etkisi Testi}

Çalışmada aracılık etkisini test etmek için, Baron ve Kenny (1986) tarafindan önerilen üç koşullu yöntem temel alınmıştır. Bu yöntemin ilk koşulu olan bağımsız değişkenin bağımlı değişken üzerindeki etkileri test edilmiştir. E-atmosferin plansız satınalma üzerinde etkili olduğu anlaşılmıştır (standardize $\beta=0,61 ; \mathrm{p}<0,01$, Kritik Oran=9,685, Standart Hata $=0,08, \mathrm{R}^{2}=0,38$; modelin uyum değerleri: $X^{2}=418,790 ; \mathrm{df}=202 ; X^{2} / \mathrm{df}=2,073$; $\mathrm{GFI}=0,855$; $\mathrm{CFI}=0,966 ; \mathrm{NFI}=0,937 ; \mathrm{RMSEA}=0,068$ ). Sözkonusu değerler kabul edilebilir sınırlar içinde olduğundan (Malhotra, 2010:732,733) ve etki anlamlı olduğundan birinci koşul sağlanmıştır.

Baron ve Kenny (1986) tarafından önerilen yöntemin ikinci ve üçüncü koşullarını test edebilmek amacıyla aracı değişkenin (alışveriş keyfi) dahil edildiği yapısal eşitlik modeli testi uygulanmıştır (Model uyum değerleri: $X^{2}=570,369 ; \mathrm{df}=266 ; X^{2} / \mathrm{df}=2,144 ; \mathrm{GFI}=0,829 ; \mathrm{CFI}=0,961 ; \mathrm{NFI}=0,929$; RMSEA=0,070). Elde edilen bulgulara göre ikinci koşul olan bağımsız değişkenin aracı değişken üzerinde istatistiksel olarak anlamlı etkiye sahip olması şartının sağlandığı ve e-atmosferin alışveriş keyfi üzerinde pozitif ve anlamlı bir etkiye sahip olduğu tespit edilmiştir $(\beta=0,81, p<0,01$, Kritik Oran=15,747; Standart Hata=0,07; $\mathrm{R}^{2}=0,66$ ). Böylece aracılık etkisi testinin ikinci koşulu da sağlanmıştır.

Baron ve Kenny (1986) yönteminde önerilen üçüncü koşulun ilk şartı, aracı değişkenin bağımlı değişken üzerinde anlamlı etkiye sahip olmasıdır. Analiz sonucuna göre, alışveriş keyfi plansız satın alma üzerinde pozitif ve anlamlı bir etkiye sahiptir $(\beta=0,71, \mathrm{p}<0,01$; Kritik Oran=7,807; Standart Hata=0,09; $\left.\mathrm{R}^{2}=0,55\right)$. Böylece üçüncü koşulun ilk şartı sağlanmış ve ayrıca $\mathbf{H 3}$ hipotezi desteklenmiştir. Aracılık etkisinde gerekli olan üçüncü koşulun diğer şartı ise, bağımsız değişkenin bağımlı değişken üzerindeki etkisinin aracı değişkenin modele dahil olması ile birlikte azalması veya ortadan kalkmasıdır. E-atmosferin plansız satın alma üzerindeki istatistiksel olarak anlamlı olan etkisi, alışveriş keyfinin aracı değişken olarak modele dahil edilmesi durumunda ortadan kalkmıştır $\left(\beta=0,04 ; p=0,628 ;\right.$ Kritik Oran=0,485; Standart Hata=0,109; $\left.\mathrm{R}^{2}=0,66\right)$ ve böylece üçüncü koşul sağlanmıştır. Şekil 3'de aracılık testi sonucu bulguları yer almaktadır. 


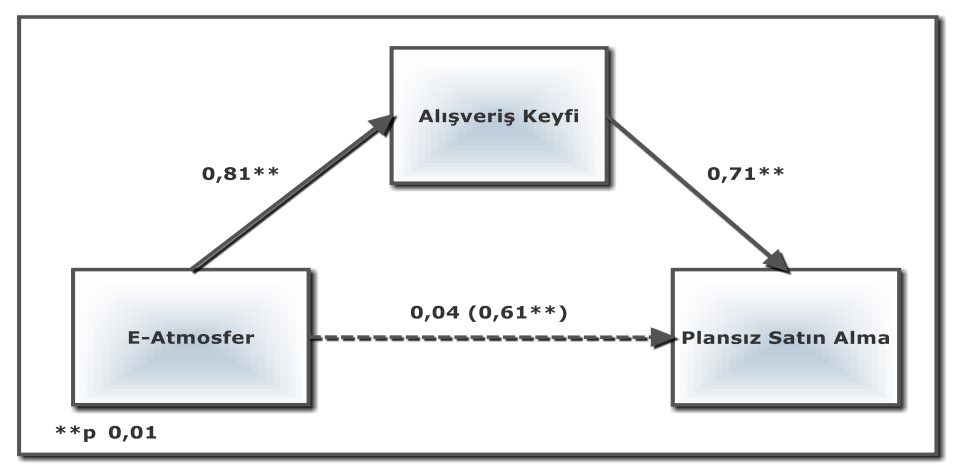

Şekil 3. Alışveriş Keyfi Aracı Etkisi Modeli

Şekil 3'de görüldüğü gibi, aracı değişken olan alışveriş keyfi modelde yer almadığında e-atmosfer plansız satınalma üzerinde yüksek ve anlamlı bir etkiye sahipken $(\beta=0,61, p<0,01)$, modele alışveriş keyfi eklenince bu etki istatistiksel olarak anlamsız hale gelmektedir $(\beta=0,04, p=0,628)$. Bu bulgulara dayanarak, e-atmosfer ile plansız satın alma arasındaki ilişkide, alışveriş keyfinin tam aracılık rolü olduğu anlaşılmıştır. Bu bağlamda, H4 hipotezi desteklenmiştir.

\section{Atmosfer Duyarlılığı Düzeylerine Göre Modelin Test Edilmesi}

Alışveriş keyfinin, e-atmosfer ile plansız satın alma ilişkisindeki aracılık rolünün cevaplayıcıların atmosfer duyarlılığı düzeylerine (yüksek/düşük) göre fark gösterip göstermediğini test etmek amacıyla atmosfer duyarlılık ölçeği için medyan değeri hesaplanmış (medyan=3,50) ve örneklem, atmosfer duyarlılığı düşük (ortalama $\leq 3,50 ; n=129$ ) ve yüksek (ortalama>3,50; n=105) olmak üzere iki gruba ayrılmıştır. Araştırma anketinde yer alan tüm ölçeklerin her bir maddesi için iki grubun cevapları arasında istatistiksel olarak anlamlı bir fark olup olmadığını tespit etmek amacıyla bağımsız örneklem t-testi uygulanmış ve tüm ölçek maddeleri için gruplar arasında anlamlı farklılıklar olduğu tespit edilmiştir.

Atmosfer duyarlılığ 1 düşük olan grup için, aracılık testi öncesinde, e-atmosferin plansız satın alma üzerindeki etkisi istatistiksel olarak anlamlı $(\beta=0,63, p<0,01)$ iken; alışveriş keyfi modele aracı değişken olarak eklendiğinde, e-atmosferin plansız satın alma üzerindeki etkisinin ortadan kalktığı ve istatistiksel olarak anlamsız hale geldiği tespit edilmiştir $(\beta=0,07, p=0,59)$. Söz konusu modelde alışveriş keyfinin plansız satın alma üzerinde istatistiksel olarak anlamlı $(\beta=0,65, p<0,0$, Kritik Oran=4,792; Standart Hata $=0,11 ; \mathrm{R}^{2}=0,51$ ) etkiye sahip olduğu görülmüştür (Model uyum değerleri: $X^{2}=531,197 ; \mathrm{df}=266 ; X^{2} / \mathrm{df}=1,997 ; \mathrm{GFI}=0,763 ; \mathrm{CFI}=0,940 ; \mathrm{NFI}=0,887$; RSEA=0,088).

Atmosfer duyarlılığı yüksek olan grup için, aracılık testi öncesinde e-atmosferin plansız satın alma üzerinde (duyarlılı̆̆ı düşük gruptan farklı olarak) 0,01 anlamlılık düzeyinde etkisiz, ancak 0,05 anlamlılık düzeyinde etkili olduğu tespit edilmiştir $(\beta=0,22, p=0,04)$. Bu bağlamda, Baron ve Kenny (1986) koşulu sağlandığından, alışveriş keyfinin aracılık etkisini ölçmek amacıyla aracılık model testi uygulanmıştır. Elde edilen bulgulara göre, alışveriş keyfi değişkeni modele dahil edildiğinde, eatmosferin plansız satın alma üzerindeki etkisi istatistiksel olarak anlamsız hale gelmiştir $(\beta=-0,04$, 
$\mathrm{p}=0,73)$. Aynı modelde alışveriş keyfinin plansız satın alma üzerinde istatistiksel olarak anlamlı $\left(\beta=0,60, p<0,0\right.$, Kritik Oran=5,429; Standart Hata $\left.=0,16 ; \mathrm{R}^{2}=0,34\right)$ etkisi olduğu tespit edilmiştir (Model uyum değerleri: $X^{2}=457,189 ; \mathrm{df}=266 ; X^{2} / \mathrm{df}=1,719 ; \mathrm{GFI}=0,758 ; \mathrm{CFI}=0,914 ; \mathrm{NFI}=0,819$; RMSEA=0,083).

Böylece, bulgular incelendiğinde, atmosfer duyarlılığı düşük ve yüksek olmak üzere her iki grup için de, alışveriş keyfi değişkeninin e-atmosfer ve plansız satın alma davranışı ilişkisinde tam aracılık rolü olduğu görülmektedir.

\section{Bulguların Tartışılması, Sonuç ve Öneriler}

E-atmosferin plansız satın alma ve alışveriş keyfi üzerindeki etkisinin araştırılması ve ek olarak eatmosfer ile plansız satın alma davranışı ilişkisinde alışveriş keyfinin aracılık etkisinin, atmosfer duyarlılı̆̆ düzeylerine göre incelenmesinin amaçlandığ 1 bu çalışma Trendyol ve Morhipo e-ticaret sitelerinden alışveriş yapan ve çoğunluğu kadın olan 234 cevaplayıcı ile gerçekleştirilmiştir. Çoğunluğu 21-25 yaş grubunda olan cevaplayıcıların, söz konusu siteleri ağırlıklı olarak ayda ortalama 2-5 defa ziyaret ettikleri ve en sık satın aldıkları ürün grubunun giyim olduğu tespit edilmiştir. İki e-ticaret sitesi karşılaştırıldığında, Trendyol'un e-atmosfer açısından daha yüksek ortalamalar elde ettiği görülmüştür.

Araştırma hipotezlerini test etmek amacıyla ilk olarak e-atmosferin plansız satın alma üzerindeki etkisi test edilmiştir. Geçmiş çalışmalarda (örneğin, Adelaar, 2003; Verhagen ve VanDolen, 2011) elde edilen bulgulara paralel olarak, e-atmosferin plansız satın alma üzerinde pozitif yönlü ve istatistiksel olarak anlamlı bir etkisi olduğu tespit edilmiştir. Diğer bir deyişle, web sitelerinde eatmosferin hedef kitleye uygun şekilde tasarlanması, ziyaretçilerin plansız satın alma davranışı göstermelerinde etkili olmaktadır. Benzer şekilde, araştırma bulgularına göre, e-atmosferin alışveriş keyfi üzerinde de istatistiksel olarak anlamlı etkisi olduğu görülmektedir. Elde edilen bu bulguya göre e-atmosfer, web sitesini ziyaret eden tüketicilerin alışverişten keyif alma düzeylerini etkilemektedir. Ayrıca Trendyol'un, Morhipo ile karşılaştırıldığına, e-atmosfer ve alışverişten keyif alma ölçeklerinde daha yüksek ortalamalara sahip olması, farklı e-atmosfere sahip sitelerden, tüketicilerin farklı düzeylerde keyif aldıklarına işaret etmektedir.

Geçmiş çalışmalar incelendiğinde, e-atmosferin tüketicilerde duygusal tepkiler oluşturduğu (örneğin, $\mathrm{Wu}$, Cheng ve Yen, 2008) ve farklı yönlerden tüketici davranışlarını etkilediği (örneğin, Manganari, Siomkos ve Vrechopoulos, 2009) yönünde araştırmalara rastlanmaktadır. Bu bağlamda, bu araştırmada, alışveriş keyfinin e-atmosfer ve plansız satın alma arasındaki ilişkideki aracılık rolü test edilmiştir. Beklendiği üzere ve geçmiş çalışma bulgularına paralel olarak, e-atmosferin plansız satın alma üzerindeki doğrudan etkisi, modele alışveriş keyfi değişkeninin eklenmesi ile ortadan kalkmış ve e-atmosfer söz konusu modelde yalnızca alışveriş keyfi üzerinden dolaylı olarak plansız satın alma üzerinde etkili bulunmuştur. Diğer bir deyişle, e-atmosfer plansız satın alma üzerinde doğrudan etkili olsa da, her alışverişin, tüketicilerde olumlu veya olumsuz düzeyde alışveriş keyfi oluşturması beklentisi göz önünde bulundurulduğunda, e-atmosferin öncelikle alışveriş keyfi düzeyini etkilemesi ve bu yolla plansız satın almayı teşvik ettiği bulgusu ilgili literatür ile paralellik göstermektedir. Bu bulgular göz önünde bulundurularak, e-ticaret firmalarına web sitesi tasarımlarını planlarken e- 
atmosferlerini ziyaretçilerin alışveriş keyfini artıracak şekilde tasarlamaları önerisinde bulunmak mümkündür. Dolayısıyla, araştırma bulgularına göre denilebilir ki, e-mağazadaki alışveriş keyfinin artırılması ziyaretçileri sitede plansız alışveriş yapmaya daha çok teşvik edecektir.

Atmosfer duyarlılığı düzeylerine göre (düşük/yüksek) aracılık testi tekrarlandığında, beklenen durumdan farklı olarak, her iki grup için de, tüm örneklem ile paralel şekilde, alışveriş keyfinin tam aracıllk rolü üstlendiği görülmüştür. Bu bağlamda, atmosfer duyarlllık düzeyleri arasındaki fark göz önünde bulundurulmaksızın, e-atmosferin plansız satın alma davranışında her iki grup için de alı̧veriş keyfi üzerinden etkili olduğu ortaya konmuştur. Özetle, e-mağaza ziyaretçisi, ister yüksek, ister düşük alışveriş duyarlllığına sahip olsun, alışverişten keyfi aldığı sürece plansız satın alma ihtimali artmaktadır. Bu sebeple e-mağaza sahiplerinin ziyaretçilerini plansız satın almaya yönlendirmek arzuları bulunması durumunda e-atmosferlerini alışveriş keyfi yaratacak şekilde tasarlamaları tavsiye edilir.

\section{Araştırma Kısıtları}

Her çalışmada olduğu gibi bu çalışma da bazı kısıtlar içermektedir. Araştırmada zaman ve maliyet kısıtları nedeniyle tesadüfi olmayan örnekleme yöntemlerinden kolayda örnekleme kullanılmıștır. Bu bağlamda araştırma sonuçları yalnızca araştırmaya dahil edilen örneklem için geçerli olup, geneli yansıtmak açısından sınırlıdır. Araştırma kapsamına yalnızca iki e-ticaret sitesi dahil edilmiştir. Konu ile ilgili yapılacak yeni araştırmalarda farklı araştırma sitelerinin de araştırma kapsamına alınması, farklı örneklemler kullanılması ve tesadüfi örnekleme yöntemleri ile örneklem seçilmesi bulguların genelleştirilmesi açısından katkı sağlayabilir.

\section{Kaynakça}

Adelaar, T., Chang, S., Lancendorfer, K. M., Lee, B., Morimoto, M. (2003). Effects of Media Formats on Emotions and Impulse Buying Intent, Journal of Information Technology, 18, 247-266.

Arslan, F. M. (2011). Mağazacılıkta Atmosfer. İstanbul: Beta Basım Yayım Dağıtım AŞ.

Bagozzi, R. P. (1986). Principles of Marketing Management. Chicago: Science Research Associates, Inc.

Baker, J., Parasuraman, A. P., Grewal, D., Voss, G. B. (2002). The Influence of Multiple Store Environment Cues on Perceived Merchandise Value and Patronage Intentions, Journal of Marketing, 66, 120-141.

Baron, R.M., Kenny D.A. (1986). The Moderator-Mediator Variable Distinction in Social Psychological Research: Conceptual, Strategic, and Statistical Considerations. Journal of Personality and Social Psychology, 51(6), December, 1173-1182.

Beatty, S. E., Ferrell, M.E. (1998). Impulse Buying: Modeling Its Precursors, Journal of Retailing, 74(2), 169-191. 
Bellenger, D.N., Korgaonkar, P.K. (1980). Profiling the Recreational Shopper, Journal of Retailing, 56, 77-92.

Bitner, M. J., (1992). Servicescapes: The Impact of Physical Surroundings on Customers and Employees, Journal of Marketing, 56, 57-71.

Bressolles, G., Durrieu, F. Giraud, M. (2007). The Impact of Electronic Service Quality's Dimensions on Customer Satisfaction and Buying Impulse, Journal of Customer Behavior, 6(1) 37-56.

Chang H. H., Chen, S. W.(2008). The impact of Online Store Environment Cues on Purchase Intention: Trust and Perceived Risk As A Mediator, Online Information Review, 32, 818-841.

Dahlen, M., Lange, F. (2002). Real Consumers in the Virtual Store, Scandinavian Journal of Management, 18(2002), 341-363.

Daily, L. (2004). Navigational Web Atmospherics Explaining the Influence of Restrictive Navigation Cues, Journal of Business Research, 57, 795-803.

Davis, L., Wang, S., Lindridge, A. (2008). Culture Influences on Emotional Responses to On-line Store Atmospheric Cues, Journal of Business Research, 61,806-812.

Deng, L., Poole, M.S., (2012). Aesthetic Design of E-Commerce Web Pages - Webpage Complexity, Order and Preference, Electronic Commerce Research and Applications, 11(2012), 420-440.

Donovan, R. J., Rossiter, J. R. (1982). Store Atmosphere: An Environmental Psychology Approach, Journal of Retailing, 58, 34-57.

Eroglu, S. A., Machleit, K. A., \& Davis, L. M. (2001). Atmospheric Qualities of Online Retailing: A Conceptual Model and Implications. Journal of Business Research, Special Issue on Retail Strategy and Consumer Decision Research, 54, 177-184.

Eroglu, S. A., Machleit, K. A., Davis, L. M. (2003). Empirical Testing of a Model of Online Store Atmospherics and Shopper Responses. Psychology \& Marketing, 20, 139-150.

Fiore, A.M. and Kim, J. (2007). An Integrative Framework Capturing Experiential and Utilitarian Shopping Experience. International Journal of Retail \& Distribution Management, 35(6), 421442.

Floh, A., Madlberger M. (2013). The Role of Atmospheric Cues in Online Impulse-Buying Behavior. Electronic Commerce Research and Applications, 12, 425-439.

Grossbart, S., Hampton, R., Rammohan, B. and Lapidus, R.S. (1990). Environmental dispositions and customer response to store atmospherics. Journal of Business Research, 21, 224- 5.

Hausman, A.V., Siekpe, J.S. (2009). The Effect of Web Interface Features on Consumer Online Purchase Intentions. Journal of Business Research, 62, 5-13.

http://www.tuik.gov.tr/HbPrint.do?id=24862, 24.04.2018.

https://www.alexa.com/topsites/category/Top/World/T\%C3\%BCrk\%C3\%A7e/Al\%C4\%B1\%C5\%9F veri\%C5\%9F/\%C3\%87ok_\%C3\%87e\%C5\%9Fitli_\%C3\%9Cr\%C3\%BCnler, 24.04.2018. 
Kim, H., Fiore, A. M., Niehm, L. S., Jeong, M. (2010). Psychographic Characteristics Affecting Behavioral Intentions Towards Pop-Up Retail, International Journal of Retail \& Distribution Management, 38, 133 - 154.

Kim, J., Fiore, A. M., Lee, H. H. (2007). Influences of Online Store Perception, Shopping Enjoyment, and Shopping Involvement on Consumer Patronage Behavior Towards An Online Retailer, Journal of Retailing and Consumer Services, 14, 95-107.

Kim, J.H., Kim, M., Lennon, S.J. (2009). Effects of Web Site Atmospherics on Consumer Responses: Music and Product Presentation. Direct Marketing: An International Journal, 3, 4-19.

Koo, D. M., Ju, S. H. (2010). The Interactional Effects of Atmospherics and Perceptual Curiosity on Emotions and Online Shopping Intention. Computers in Human Behavior, 26(3), 377-388.

Koo, W., Park, H. (2017). Critical Atmospheric Cues in Designing Online Stores: The Case of Amazon.com. International Journal of Marketing Studies, 9, 37-45.

Kotler, P. (1973-1974). Atmospheric as a Marketing Tool. Journal of Retailing, 49, 48-64.

Koufaris, M. (2002). Applying the Technology Acceptance Model and Flow Theory to Online Consumer Behavior, Information Systems Research, 13, 205-223.

Koufaris, M., Kambil, A., Labarbera, P.A. (2001). Consumer Behavior in Web-Based Commerce: An Empirical Study. International Journal of Electronic Commerce, 6(2), 115-138.

Li, Y., (2011). Motivations for eWOM Communication in Microblogging in U.S. and China : a Conceptualized Social Cognitive Perspective. The University of Texas, The Faculty of the Graduate School, Master Thesis.

Malhotra, N. (2010). Marketing Research, An Applied Orientation (6th Ed.). New Jersey, USA: Pearson Education Inc.

Manganari, E.E., Siomkos, G. J., Vrechopoulos, (2009). Store atmosphere in web retailing. European Journal of Marketing, 43(9/10), 1140-1153.

Mattila A. S., Wirtz J.(2001). Congruency of Scent and Music as a Driver of in-store Evaluations and Behavior. Journal of Retailing, 77, 273-289.

Mazaheri E., Richard M. O., Laroche M., Ueltschy L. C. (2013). The Influence of Culture, Emotions, Intangibility, and Atmospheric Cues on Online Behavior. Journal of Business Research, 67, 253259.

McKechnie, G. E. (1974). Manual for the environmental response inventory, Palo Alto, CA: Consulting Psychologists Press; akt. Eroglu, S. A., Machleit, K. A., \& Davis, L. M. (2001). Atmospheric qualities of online retailing: A conceptual model and implications. Journal of Business Research, Special Issue on Retail Strategy and Consumer Decision Research, 54, 181.

McKinney, L. N. (2004). Creating a Satisfying Internet Shopping Experience via Atmospheric Variables. International Journal of Consumer Studies, 28, 268-283.

Mehrabian, A., Russell, J. A., (1974). An Approach to Environmental Psychology. MIT Press, Cambridge. 
Mohan, G., Sivakumaran, B., Sharma P. (2013). Impact of Store Environment on Impulse Buying Behavior. European Journal of Marketing, 47, 1711-1732.

Morrin, M., Chebat, J. C., (2005). Person-Place Congruency: The Interactive Effects of Shopper Style and Atmospherics on Consumer Expenditure. Journal of Service Research, 8(2), 181-191.

Nunnaly, J. (1978). Psychometric Theory. New York, NY: McGraw-Hill.

Fornell, C., Larcker, D.F. (1981). Evaluating Structural Equation Models with Unobservable Variables and Measurement Error. Journal of Marketing Research, 18, 39-50.

Özgüven T. N. (2015). Market Alışverişlerinde Plansız Satın Alma Davranışında Demografik Farklılığı Belirlemeye Yönelik Bir Araştırma. Selçuk Ün. Sos. Bil. Ens. Dergisi. 1(34), 87-94.

Özmen, Ş. (2009). A $\breve{g}$ Ekonomisinde Yeni Ticaret Yolu E-ticaret (Geliştirilmiş 3. Baskı), İstanbul: İstanbul Üniversitesi.

Parboteeah, D.V., Valacich, J. S., Wells, J. D. (2009). The Influence of Website Characteristics on a Consumer's Urge to Buy Impulsively. Information Systems Research, 20, 60-78.

Rook, D. W. (1987). The Buying Impulse.. Journal of Consumer Research, 14, 189-199.

Russel, J. A., and J. Snodgrass (1987). Emotion and Environment., in Handbook of Environmental Psychology, 1(1), 245-80.

Sherman, E., Mathur, A., Smith, R.B. (1997). Store Environment and Consumer Purchase Behavior: Mediating Role of Consumer Emotions. Psychology and Marketing, 14(7), 361-378.

Shun, C., Yunjie, X. (2006). Effects of Outcome, Process and Shopping Enjoyment on Online Consumer Behaviour. Electronic Commerce Research and Applications, 5, 272-281.

Spies, K., Hesse, F. and Loesch, K. (1997). Store Atmosphere, Mood and Purchasing Behavior. International Journal of Research in Marketing, 14, 1-17.

Stern, H. (1962). The significance of Impulse Buying Today. Journal of Marketing, 26,59-62.

Turley, L.W., Milliman, R.E. (2000). Atmospheric Effects on Shopping Behavior: A Review of the Experimental Evidence. Journal of Business Research, 49, 193-211.

Verhagen, T., Dolen, W. (2011). The Influence of Online Store Beliefs on Consumer Online Impulse Buying: A Model and Empirical Application. Information \& Management, 48, 320-327.

Wu, C. S., Cheng F. F., Yen, D. C. (2008). The Atmospheric Factors of Online Storefront Environment Design: An Empirical Experiment in Taiwan. Information \& Management, 45, 493-408.

$\mathrm{Xu}, \mathrm{Y}$. (2007). Impact of Store Environment on Adult Generation Y Consumers' Impulse Buying. Journal of Shopping Center Research, 14, 39-56.

Yeniçeri, T., Yaraş, E. ve Akın, E. (2012). Tüketicilerin Riskten Kaçınma Düzeylerine Göre Sanal Alışveriş Risk Algısı ve Sanal Plansız Tüketim Eğilimlerinin Belirlenmesi. Uluslararası İktisadi ve İdari İncelemeler Dergisi, 5(9), 145-164.

Young H., Sharron J. Lennon, (2011). Consumer Responses to Online Atmosphere: The Moderating Role of Atmospheric Responsiveness. Journal of Global Fashion Marketing, 2(2), 86-94. 
EK: Ölçeklere Ait Faktör Yapıları, Ortalamalar, Standart Sapmalar, DFA Standardize 6 ve Güvenilirlik Değerleri

\begin{tabular}{|c|c|c|c|c|}
\hline Ölçek Soruları* & $\begin{array}{l}\text { Soru Ortalama } \\
\text { (Std. Sap.) }\end{array}$ & $\begin{array}{c}\text { Standardize } \\
\beta \\
\text { (DFA) }\end{array}$ & $\begin{array}{l}\text { Ölçek Ortalama } \\
\text { (Std. Sap.) }\end{array}$ & $\begin{array}{c}\text { Güvenilirlik } \\
\text { Cronbach's } \\
\text { Alfa }(\alpha)\end{array}$ \\
\hline E-Atmosfer & & & $3,29(0,97)$ & 0,972 \\
\hline Görsel Unsurlar & & & $3,43(1,08)$ & 0,966 \\
\hline Cezbedici düzen & $3,39(1,15)$ & 0,919 & & \\
\hline Çekici renk & $3,39(1,12)$ & 0,910 & & \\
\hline Hoş tasarım & $3,39(1,16)$ & 0,936 & & \\
\hline Çekici şekilde ürün sergileme & $3,48(1,15)$ & 0,916 & & \\
\hline Çekici görsel & $3,49(1,17)$ & 0,908 & & \\
\hline Bilgi Unsurları & & & $3,40(1,04)$ & 0,944 \\
\hline Güncel görünüm & $3,54(1,20)$ & 0,860 & & \\
\hline Doğru bilgiler & $3,52(1,16)$ & 0,877 & & \\
\hline Faydalı bilgiler & $3,31(1,12)$ & 0,886 & & \\
\hline Bilgilendirici site & $3,32(1,12)$ & 0,879 & & \\
\hline Sitede yeterli bilgi & $3,30(1,13)$ & 0,871 & & \\
\hline $\begin{array}{l}\text { Gezinme (Navigasyon) } \\
\text { Unsurları }\end{array}$ & & & $3,52(1,10)$ & 0,950 \\
\hline $\begin{array}{l}\text { Sitenin rahat gezinti olanağı } \\
\text { sağlaması }\end{array}$ & $3,50(1,18)$ & 0,896 & & \\
\hline Geçerli bağlantı & $3,53(1,19)$ & 0,885 & & \\
\hline Mantıklı tasarım & $3,50(1,18)$ & 0,921 & & \\
\hline Bilgilere kolay ulaşım & $3,53(1,15)$ & 0,937 & & \\
\hline Sosyal Unsurlar & & & $2,77(1,21)$ & 0,961 \\
\hline Sitede fikir paylaşım olanağı & $2,86(1,22)$ & 0,866 & & \\
\hline $\begin{array}{l}\text { Ürünlerle ilgili kullanıcı } \\
\text { yorumlarının bulunması }\end{array}$ & $2,70(1,30)$ & 0,953 & & \\
\hline $\begin{array}{l}\text { Ürünle ilgili başkalarının } \\
\text { düşüncelerine kolay ulaşım }\end{array}$ & $2,68(1,29)$ & 0,975 & & \\
\hline $\begin{array}{l}\text { Başkalarının ürünle ilgili } \\
\text { değerlendirme ve } \\
\text { puanlamalarına kolay ulaşım }\end{array}$ & $2,83(1,29)$ & 0,920 & & \\
\hline Alışveriş Keyfi & & & $3,65(1,27)$ & 0,966 \\
\hline $\begin{array}{l}\text { Alışverişin eğlenceli bir } \\
\text { aktivite olması }\end{array}$ & $3,71(1,30)$ & 0,983 & & \\
\hline Alışverişin kişiyi mutlu etmesi & $3,73(1,30)$ & 0,967 & & \\
\hline
\end{tabular}




\begin{tabular}{|c|c|c|c|c|}
\hline $\begin{array}{l}\text { Alışverişin kişinin en sevdiği } \\
\text { aktivitelerden biri olması }\end{array}$ & $3,51(1,35)$ & 0,905 & & \\
\hline Plansız Satın Alma & & & $3,07(1,15)$ & 0,926 \\
\hline $\begin{array}{l}\text { İnternette gezinirken kişinin } \\
\text { düşünmediği şeyleri alması }\end{array}$ & $3,23(1,35)$ & 0,896 & & \\
\hline $\begin{array}{l}\text { İnternetten rastgele bir şeyler } \\
\text { almanın eğlenceli olması }\end{array}$ & $3,03(1,32)$ & 0,899 & & \\
\hline $\begin{array}{l}\text { İnternette düşük fiyatlı } \\
\text { ürünlerin düşünmeden } \\
\text { alınması }\end{array}$ & $3,14(1,33)$ & 0,825 & & \\
\hline $\begin{array}{l}\text { İnternette ilgi çeken birşey } \\
\text { görüldüğünde nasıl olduğunu } \\
\text { görmek için alınması }\end{array}$ & $2,86(1,28)$ & 0,761 & & \\
\hline $\begin{array}{l}\text { İnternette ilk görüldüğünde } \\
\text { beğenilen ürünün alınması }\end{array}$ & $3,10(1,25)$ & $--^{* *}$ & & \\
\hline Atmosfer Duyarlılığı & & & $3,22(1,11)$ & 0,930 \\
\hline $\begin{array}{l}\text { İnternette alışveriş yapılırken } \\
\text { sanal mağaza atmosferine } \\
\text { dikkat edilmesi }\end{array}$ & $3,41(1,22)$ & 0,722 & & \\
\hline $\begin{array}{l}\text { Sanal mağaza atmosferinin } \\
\text { sanal mağaza tercihini } \\
\text { etkilemesi }\end{array}$ & $3,30(1,24)$ & 0,863 & & \\
\hline $\begin{array}{l}\text { Sanal mağaza görüntüsünün } \\
\text { farketmeden alışveriş } \\
\text { yaptırması }\end{array}$ & $3,08(1,21)$ & 0,919 & & \\
\hline $\begin{array}{l}\text { Sanal mağaza tasarımının } \\
\text { nereden alışveriş yapılacağını } \\
\text { etkilemesi }\end{array}$ & $3,12(1,22)$ & 0,947 & & \\
\hline
\end{tabular}

*Sorunlar ankette yer alan orijinal halinde olmayıp, tablo için kısaltılmıştır.

**DFA sonucunda modifikasyon yapılarak bu soru analizden çıkarılmıştır. 